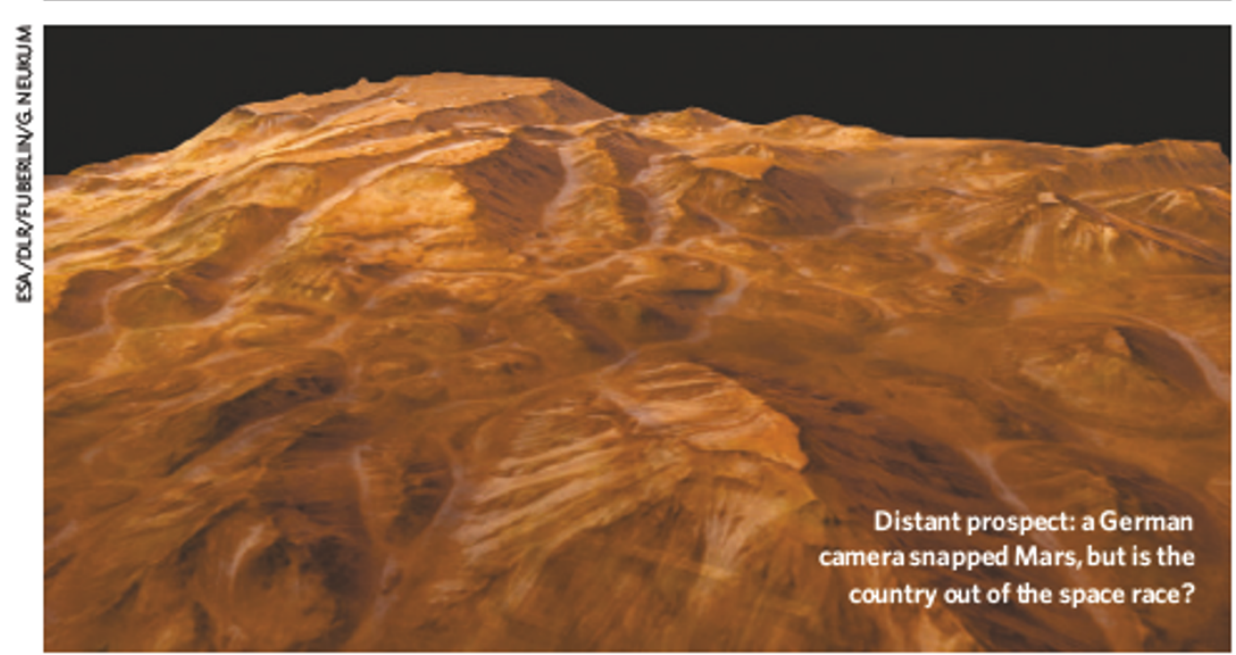

\title{
Shrinking budget grounds German space research
}

\section{MUNICH}

Germany was once a leader in space research. The Mars Express pictures that fired the world's imagination last year were taken by a German stereocamera, for example. And the APX 'sniffer' that first analysed the chemistry of martian rocks on NASA's 1997 Sojourner mission was also German.

But Germany's space research budget has shrunk by so much that the country's scientists say they no longer have the opportunity to participate in space missions. Frustrated by the government's failure to reverse the trend, they are warning that, without involvement in missions, the country's space-related research laboratories will inevitably wind down too.

Since reunification in 1990 put pressure on the country's spending as a whole, the space research budget has slipped every year. Its value is now only a third of what it was 15 years ago. Top astronomers, planetary scientists and climatologists have been discussing the crisis with politicians for months - but to no avail, say the researchers.

So on 21 June, the scientists published what they refer to as a "begging letter". No national space-science mission is planned for the next five years, they point out. And to make matters worse, they say they are unable to compete in placing instruments on international missions either.

Although Germany's space budget is shrinking each year, the country is locked into paying the highest contribution to the European Space Agency's science budget, based on its high GDP. This means that Germany is paying for ESA's spacecraft and launches, but there isn't enough national money left over for German scientists to develop their own instruments to send on board, according to Günter Hasinger, a director of the Max Planck Institute for Extraterrestrial Physics in Garching.

For example, although the APX spectrometer is to be included in NASA's Mars Science Laboratory (due for launch in 2009 or 2011), it will be developed in Canada, not Germany because the department that first worked on it, at the Max Planck Institute for Chemistry in Mainz, has closed.

The extraterrestrial-physics institute is also rethinking its strategy, and has abandoned gamma-ray astronomy to concentrate all its efforts on X-ray astronomy, says Hasinger.

And environmental scientists are complaining that they don't have enough money to exploit Europe's Earth observation satellites. “Germany is a big contributor to Earth observation hardware," says Jochem Marotzke, an oceanographer and a director at the Max Planck Institute for Meteorology in Hamburg. ${ }^{\alpha}$ But we have little project money to make use of it."

When asked about the crisis, a research ministry spokesman told Nature that space research remains a "high priority" for the German government. Scientists are hoping that, with an election looming, their public plea will help persuade politicians to back that sentiment with further funds.

Alison Abbott 